\title{
Nan Goldin's the Ballad of Sexual Dependency
}

Quote: BOONE, Silvana. Nan Goldin's the Ballad of Sexual Dependency. Porto Arte: Revista de Artes Visuais. Porto Alegre: PPGAV-UFRGS, v. 23, n. 38, p.13, jan.jun. 2018. e-ISSN 2179-8001. DOI: http://dx.doi.org/10.22456/21798001.80809

Translated by Roberto Cataldo Costa

Abstract: This review focuses on American artist Nan Goldin's exhibition The Ballad of Sexual Dependency, held at MoMA The Museum of Modern Art in New York - in 2016-2017, 30 years after her first exhibition in 1986. The slideshow is a highlight with about 700 photographs produced by the artist between the 1970 s and 1990 s, which show the nature of the social group to which she belonged.

Keywords: Nan Goldin. Exhibition. Contemporary art. Photography. Public.

It is possible to see the impact of an exhibition on the general public when we are directly struck by the artist's work as individuals. Nan Goldin's "The ballad of sexual dependency" has enough visual strength to throw us abruptly into the underground universe experienced by the artist and recorded through photography. It presents an experience so deep that viewers cannot avoid being immersed in a world that is not theirs.

As a slideshow of about 700 photographs produced between the 1970s and 1990s and including an eclectic soundtrack, "The Ballad of Sexual Dependence" stresses the nature of the social group to which the artist belonged. In addition to the commemorative character allusive to the first exhibition held in New York in 1986, 30 years later this new exhibition reiterates the legitimacy that MoMA ascribes to the artist as an icon of contemporary art, since its collection includes almost all the images of the exhibition.

MoMA's curatorial staff - Chief Curator at Large and Director Klaus Biesenbach, Chief Curator of The Celeste Bartos Film Program Rajendra Roy, and Assistant Curator in the Department of Photography Lucy Gallun - presented the slides in their original $35 \mathrm{~mm}$ format, shown on nine sequenced projectors and keeping the same original aura of previous editions. The curatorial staff began to build the exhibition space with a large corridor that served as a historical setting for the public, almost as didactic guidance, exhibiting some of the most well-known photographs that were part of the slideshow, the original catalogs, books published, brochures, posters - some of which were handmade - of the first exhibitions, including the 1984 Berlin poster.

Considered as a diary, the exhibition features images captured between Goldin's hometown Boston, New York, and Berlin, accompanied by an intense soundtrack that goes from American rock band Velvet Underground to Maria Callas's classic opera, which gives it the exact tone of the atmosphere charged with the images and turns the exhibition ensemble into much more than a photo exhibition; it is rather a dramatic theatrical act or yet a pseudo-tragedy in which love, sex, drugs, losses and pain share the space with the subjects photographed.

When producing the photographic images of her daily life and her surroundings, Nan Goldin used to occupy space with her photographic equipment, which was far from invisible to the subjects of her photography. However, that did not prevent her from recording everything without asking for permission. She also used a remote shutter to take the photos in which she was the subjects (Figure 1), alone or accompanied in moments of intimacy. Long before the emergence of selfies or the visual avalanche caused by the use of cell phone cameras, Goldin could be considered a voyeur in the open, since the fact of invading the privacy of her groups was somehow explicit and in no way prevented her from recording moments at their truest intensity.

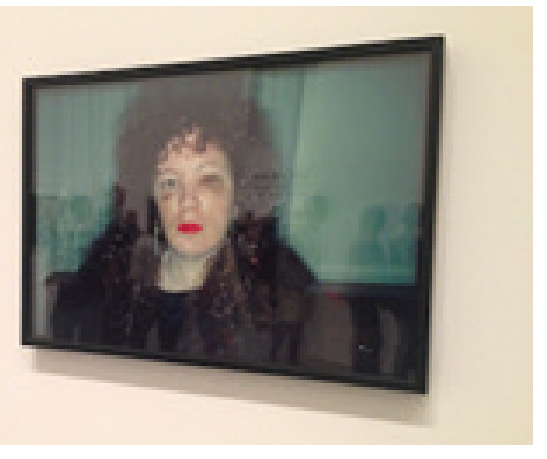

Figure 1. Nan Goldin, Nan one month after being battered, 1984. Partial view of the exhibition The ballad of sexual dependency, 2016, MoMA. Photo: Silvana Boone

By - literally - revealing everyday reality, Nan Goldin makes the ballad her diary: 
The Ballad of Sexual Dependency is the diary I let people read. My written diaries are private; they form a closed document of my world and allow me the distance to analyze it. My visual diary is public; it expands from its subjective basis with the input of other people. These pictures may be an invitation to my world, but they were taken so that I could see the people in them. I sometimes don't know how I feel about someone until I take his or her picture. I don't select people in order to photograph them; I photograph directly from my life. These pictures come out of relationships, not observation. ${ }^{1}$

As a visual diary, the "ballad" records the alternative behavior of her family group, but also the suffering caused by AIDS, between illness and death, victimizing some of her drug-addicted and transsexual friends leading a sexually unruly life. The public album of memories becomes the record of a tragic reality, of the open private life that goes from love to death, in which photographic improvisation reveals the final act of some lives.

Despite the realistic and almost documentary character of the photographs' aesthetic quality, it should be stressed that "in Goldin's work there is no hidden documentary or ideological intention, there is no neorealist mission"2, that is, the intentionality of the images directs us to thinking about the record, but also about photography's role as contemporary art:

The Ballad was radically challenging prevailing theory and practice, which viewed photography as the poor relative of painting. Her slide presentations, besides reasserting the serial nature of photography, referred directly to the intangibility of the medium, establishing a revolutionary association between the latter and the language of cinema. ${ }^{3}$

Goldin's "ballad" can be considered an emblematic exhibition in the context of contemporary art if we think that few exhibitions have been ever re-edited and, in this case, with virtually the same format. MoMA was one of the first museums in the world to have a dedicated photography department ${ }^{4}$, and the images are part of its large photographic collection. According to Charlotte Cotton, "although Goldin started taking pictures of her friends in the early 1970s, it was not until the early 1990 s that her work gained international recognition and entered the art market" ${ }^{\prime \prime}$. Re-presenting the same exhibition after 30 years can be seen as a curatorial strategy to reinforce

1. GOLDIN, 2012, p. 6.

2. COSTA, 2010, p. 7.

3. Ibidem, p. 9.

4. PERL, 2008.

5. COTTON, 2013, p. 138. the artist's importance in the contemporary context, but it should be emphasized that in 1985 the same production was already significant for the standards of that time.

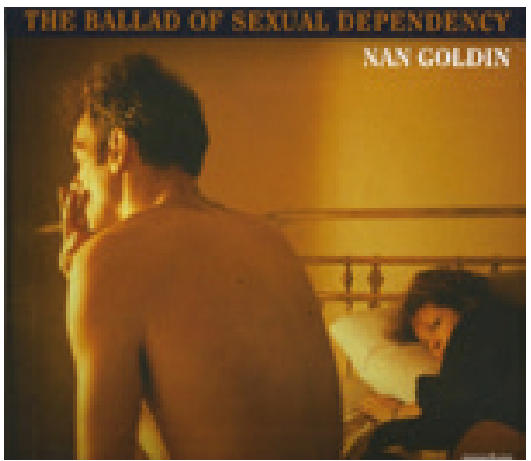

Figure 2. Cover of The ballad of sexual dependency, Aperture, 2012. Photo: Silvana Boone

The highlights of the 2016 exhibition are its repercussion in the press and the re-edition of the book/catalog released in 1986 by Aperture in New York, re-launched in 2012 in the same format and which serves again as the official catalog of the exhibition (Figure 2).

The exhibition was a unique opportunity for today's public to see Goldin's work just as it was conceived 30 years ago, for an approximation with 1980s thinking on photography and art, and to see how the concepts of contemporary art were debated based on an exhibition that was courageous, a challenge to exhibition canons, and a visual account of the artist's experiences.

Like a theater play or a trash opera, Nan Goldin's The Ballad of Sexual Addiction is an experience of strong impact, an invasive exposure to the senses - it is impossible to remain indifferent to the visual and subjective appeal of its images - something as intense and painful as a punch in the stomach.

\section{INFORMATION}

Exhibition The Ballad of Sexual Dependency, by Nan Goldin

Location: MoMA - The Museum of Modern Art, New York, USA.

Period: June 11, 2016-April 16, 2017. 


\section{REFERENCES}

COSTA, Guido. Nan Goldin. First Edition in Spanish. New York: Phaidon, 2010.

COTTON, Charlotte. A Fotografia como Arte Contemporânea.

$2^{\text {nd }}$ edition. São Paulo: Editora WMF Martins Fontes, 2013.

- (ArteधFotografia)

GOLDIN, Nan. The Ballad of Sexual Dependency. $2^{\text {nd }}$ edition. New York: Aperture, 2012.

PERL, Jed. New Art City: Nova York, capital da arte moderna.

Translation by Vera Pereira, Pedro Maia Soares. São Paulo:

Companhia das letras, 2008.

Silvana Boone: holds a PhD in Visual Arts/History, Theory and Criti// cism from PPGAV-UFRGS, a Master's Degree in Communication and Semiotics from PUCSP; she is a specialist in Visual Arts from UCS and graduated in Art Education from UCS. She has been a professor at the University of Caxias do Sul since 1995, where she works as a researcher, curator and art critic.

(*)This text was submitted in September 2017. 